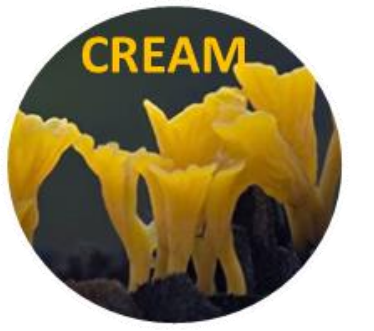

Current Research in Environmental \& Applied Mycology 6 (3): 159-165 (2016) ISSN 2229-2225

www.creamjournal.org

Article

CREAM

Copyright (C) 2016

Doi 10.5943/cream/6/3/2

Online Edition

\title{
Bioaccumulation of heavy metals in the sporocarps of some wild mushrooms
}

\author{
Lalotra $P^{1}$, Gupta $D^{1}$, Yangdol $\mathbf{R}^{1}$, Sharma $\mathbf{Y P}^{\mathbf{1}}$ and Gupta $S K^{2}$ \\ ${ }^{1}$ Department of Botany, University of Jammu, Jammu-180006, India \\ ${ }^{2}$ Department of Agro forestry, Sher-e-Kashmir University of Agricultural Sciences and Technology, Jammu-180006, India
}

Lalotra P, Gupta D, Yangdol R, Sharma YP, Gupta SK 2016 - Bioaccumulation of heavy metals in the sporocarps of some wild mushrooms. Current Research in Environmental \& Applied Mycology 6(3), 159-165, Doi 10.5943/cream/6/3/2

\begin{abstract}
The fruiting bodies of wild mushrooms show high concentrations of heavy metals due to their efficacious mechanism of accumulation of these elements from soil. In accordance with this ability, three wild macrofungi viz., Macrolepiota procera (edible species), Amanita augusta (non-edible species), Boletus subvelutipes (poisonous species) and their respective soil samples collected from different forest areas of Jammu Province were analysed for the presence of six heavy metals ( $\mathrm{Zn}, \mathrm{Cu}$, $\mathrm{Mn}, \mathrm{Fe}, \mathrm{Cd}, \mathrm{Pb}$ ). The metallic content was established by Atomic absorption spectrophotometer (AAS) and Inductively coupled Plasma-Atomic Emission spectrometry method (ICP AES). The results of heavy metals concentration are given in $\mathrm{mg}$ of metal per $\mathrm{kg}$ of dry matter and demonstrate important variation between the level of concentration in edible, non edible and toxic species. Moreover, the mean element distribution varied depending upon the part of fruiting body of macrofungi. In A. augusta these elements were detected under permissible limits for consumption. On the contrary, high ratio of zinc, copper, manganese, iron, lead and cadmium were found in A. augusta and B. subvelutipes indicating that these elements are accumulated at much higher levels in these wild growing mushrooms. Thus, it is worthwhile to evaluate the metal content in the wild macrofungi to assess their contribution to the daily intake of several toxic elements so that it would adjudicate the mushrooms for its nutritive value in terms of minerals and also define the limits of safety. As mushrooms have been known to possess good nutraceutical and pharmaceutical potential, a detailed analysis of their sporocarps is desirable before their incorporation into routine diet, drugs and medicine.
\end{abstract}

Key words - Antioxidant - edibility - elements - macrofungi - pharmaceutical

\section{Introduction}

Wild growing mushrooms form an integral part of our ecosystem. Earlier, the fruiting bodies of these non green edibles were appreciated for their texture, aroma and flavour, but now their usage is undergoing a paradigm shift as a lot of work has been focussed on their biochemical characterization (Manzi et al. 2001, Keles et al. 2011, Yildiz et al. 2015). They are considered as a delicacy with high nutritional and functional value and are also accepted as nutraceutical foods, because of presence of many bioactive compounds and minerals like zinc, manganese, copper, selenium and iron. Also, keeping in view the fact that food security to the ever exploding world's population is going to be a major challenge of $21^{\text {st }}$ century, mycologist world over are exploring ways to aware people regarding 
the nutritive value of edible mushrooms and accelerate their transformation from consuming green to these non green edibles. However, research during the past three decades on nutritive aspects of wild macrofungi has exposed their negative facet too.

The sporocarps of wild mushrooms have been found to accumulate several heavy metals predominantly the iron, arsenic, mercury, cadmium, zinc and lead in concentration above threshold. Heavy metals are defined as metallic elements that have relatively high density compared to water. It has been reported that metals such as cobalt, copper, chromium, iron, magnesium, molybdenum, selenium and zinc are essential nutrients required for various physiological functions of the body. Other metals such as mercury, nickel, silver, gallium, cadmium, aluminium have no established biological functions and are considered as non essential metals. Also, for these metals, there is a very narrow range of concentration between beneficial and toxic effects and when present above threshold level may pose serious threat to human health leading to morphological abnormalities, reduced growth and increased mortality (Olumuyiwa et al. 2007, Elekes et al. 2010, Radulescu et al. 2010).

Macrofungi have been considered as natural soil component that have a great significance in reduction of soil pollution with heavy metals. The presence of rich network of hyphae in the upper horizon of the soil explains the fact that these vegetal organisms have specific genetically controlled ability to accumulate heavy metals from their substratum (Gadd, 1993). Soil may become contaminated by the accumulation of heavy metals and metalloids through emissions from the rapidly expanding industrial areas, land application of fertilizers, coal combustion residues and spillage of petrochemicals. The presence of metals in the fruiting bodies of mushrooms directly reflects their amount in the soil and their bioaccumulation factor depicts the capacity of mushrooms to accumulate these elements from the soil. The concentration of heavy metals in the fruiting bodies of macrofungi is assumed to be species dependent but other edaphic factors like soil $\mathrm{pH}$, organic matter and clay content also play a cardinal role in accumulation and translocation of these heavy metals in mushrooms (Kalac \& Svoboda, 2000, Gursoy et al. 2009, Frankowska et al. 2010).

Literature reveals that heavy metal contamination through wild edible macrofungi to be one of the prime contributors to various disorders that are posing serious problems to human health (Das, 2005, Radulescu et al. 2010). Moreover, the inability of human system to excrete them through homeostatic filtration mechanism further leads to their accumulation in the body that eventually complicates the situation. Worldwide several workers have investigated the heavy metal concentration in many wild growing mushrooms (Isildak et al. 2004, Elekes et al. 2010, Magdziak et al. 2013, Mazurkiewicz \& Podlasinska, 2014, Dulay et al. 2015). However, from India, few scanty studies have been carried out on heavy metal accumulation by wild macrofungi (Das, 2005, Mallikarjuna et al. 2013) and as far as our literature survey could ascertain no work has been done on heavy metal estimation from the state so far.

Thus, the present investigation was undertaken for analysis of six heavy metals $(\mathrm{Zn}, \mathrm{Cu}, \mathrm{Mn}$, $\mathrm{Fe}, \mathrm{Cd}, \mathrm{Pb}$ ) in three wild mushrooms viz., Macrolepiota procera (Scop.) Singer (edible species), Amanita augusta Bojantchev \& R. M. Davis (non-edible species), Boletus subvelutipes Peck (poisonous species) collected from different regions of Jammu Province. In the perspective that wild macrofungi significantly contribute to the minerals in the diet, the data would serve as an useful basis to define the nutritive value of mushrooms along with its potent toxicity in certain species.

\section{Materials \& Methods}

\section{Biological Material}

Three species of wild mushrooms collected from different forest areas of Jammu province (Udhampur and Patnitop) were identified as Macrolepiota procera (edible species), Amanita augusta (non-edible species), Boletus subvelutipes (poisonous species) (Table 1). The fruiting bodies of these mushroom species were divided into cap and stipe portion and ashed at $100^{\circ} \mathrm{C}$ in muffle furnace in porcelain dish. In addition to the mushroom collection, soil samples of the upper forest horizon (0-10 $\mathrm{cm}$ ) after removing the surface layer of the organic detritus were also collected from appropriate sampling places. 


\section{Determination of Mineral Contents}

Total ash was taken for the analysis of mineral contents. Briefly, $2 \mathrm{~mL}$ of concentrated $\mathrm{HNO}_{3}$ was added to the ash and heated for 2 minutes. One drop of hydrogen peroxide was added into the solution to remove turbidity. The solution was then transferred into a volumetric flask and total volume was made $50 \mathrm{~mL}$ by adding deionised water. This was then used to analyze the concentration of zinc $(\mathrm{Zn})$, copper $(\mathrm{Cu})$, manganese $(\mathrm{Mn})$, iron $(\mathrm{Fe})$, cadmium $(\mathrm{Cd})$ and lead $(\mathrm{Pb})$ by flame photometry with atomic absorption spectrophotometer (Perkin Elmer A Analyst 700) and Inductively Coupled Atomic Emission Spectrophotometer (ACTIVIA - M). For estimation of heavy metal in soil samples, hot extractions with nitric acid (1:1) were done.

All the experiments were performed in triplicate and data analysis was done by mean $\pm \mathrm{SD}$ of three parallel measurements.

Table 1 Families, habitat and edibility of mushroom species.

\begin{tabular}{llllll}
\hline Sample & Mushroom species & Family & Habitat & Edibility \\
\hline 1 & $\begin{array}{l}\text { Macrolepiota procera } \\
\text { Singer } 1948\end{array}$ & Agcop.) & Agaricaceae & In open ground & Edible \\
2 & $\begin{array}{l}\text { Amanita augusta Bojantchev \& } \\
\text { R. M. Davis 2013 }\end{array}$ & Amanitaceae & In forest & Non-edible \\
3 & Boletus subvelutipes Peck 1889 & Boletaceae & In forest & Poisonous \\
\hline
\end{tabular}

\section{Results and Discussion}

In the present investigation, three wild mushrooms namely Macrolepiota procera (edible mushroom), Amanita augusta (non-edible mushroom) and Boletus subvelutipes (poisonous mushroom) were investigated for the presence of six heavy metals $(\mathrm{Zn}, \mathrm{Cu}, \mathrm{Mn}, \mathrm{Fe}, \mathrm{Cd}, \mathrm{Pb})$. The results of the heavy metals investigated in the collected wild mushrooms and their soil samples have been illustrated in Table 2.

The concentration of zinc ranged from $87.2 \pm 1.18 \mathrm{mg} / \mathrm{kg}$ to $299.0 \pm 0.86 \mathrm{mg} / \mathrm{kg}$ being lowest in $M$. procera and highest in $B$. subvelutipes. The concentration of this metal was found to be $211.1 \pm 0.86$ $\mathrm{mg} / \mathrm{kg}$ in A.augusta (Table 2 and Fig 1). Zinc was found to be accumulating more in the cap region than stipe portion depicting its higher rate of translocation in the sporocarps of wild mushrooms. Furthermore, as evident from the Table 1, a steep intensification in the bioaccumulation of this metal from the soil was observed in the toxic species as compared to edible and non edible species. Permissible range of $\mathrm{Zn}$ in mushrooms has been limited between 28.6 to $179.0 \mathrm{mg} / \mathrm{kg}$ (Tuzen et al. 2003). Zinc is one of the exigent trace elements and the chronology of events in the research of zinc biology is revealing its ever increasing variety of functions. Zinc forms an integral part of many enzymes like alcohol dehydrogenase, carboxypeptidases and other metalloproteins. It is also found to support a healthy immune system. Nevertheless, the concentration above threshold may pose serious threat to human health as excess of zinc can affect cardiac function, disturb copper metabolism and reduced immune function (Zhu et al. 2011).

The concentration of copper was found to be highest in poisonous species of $B$. subvelutipes $(290.0 \pm 1.08 \mathrm{mg} / \mathrm{kg})$ followed by A. augusta $(218.0 \pm 1.65 \mathrm{mg} / \mathrm{kg})$ and least in M. procera $(83.6 \pm 0.20$ $\mathrm{mg} / \mathrm{kg}$ ) (Table 2 and Fig 1). Cu was detected to be accumulating more in the cap region for A. augusta and B. subvelutipes and in the stipe portion for $M$. procera. In comparison to the edible species, the copper concentration showed a gradual increase from non edible to poisonous species. Copper concentration in the wild macrofungi has been reported to be in the range of 100-300 mg/kg of dry matter which is not considered to be a risk for human consumption (Kalac \& Svoboda, 2000). Under permissible range, this metal is required for normal metabolism as it is a component of haemocyanin, the blue, oxygen carrying blood pigment and is a prerequisite for the synthesis of haemoglobin, the red, oxygen carrying pigment found in the blood. However, elevated levels of copper may lead to copper toxicity that progenerate many disorders like hypoglycaemia, arthritis and low blood pressure (Zahorcova et al. 2016). 

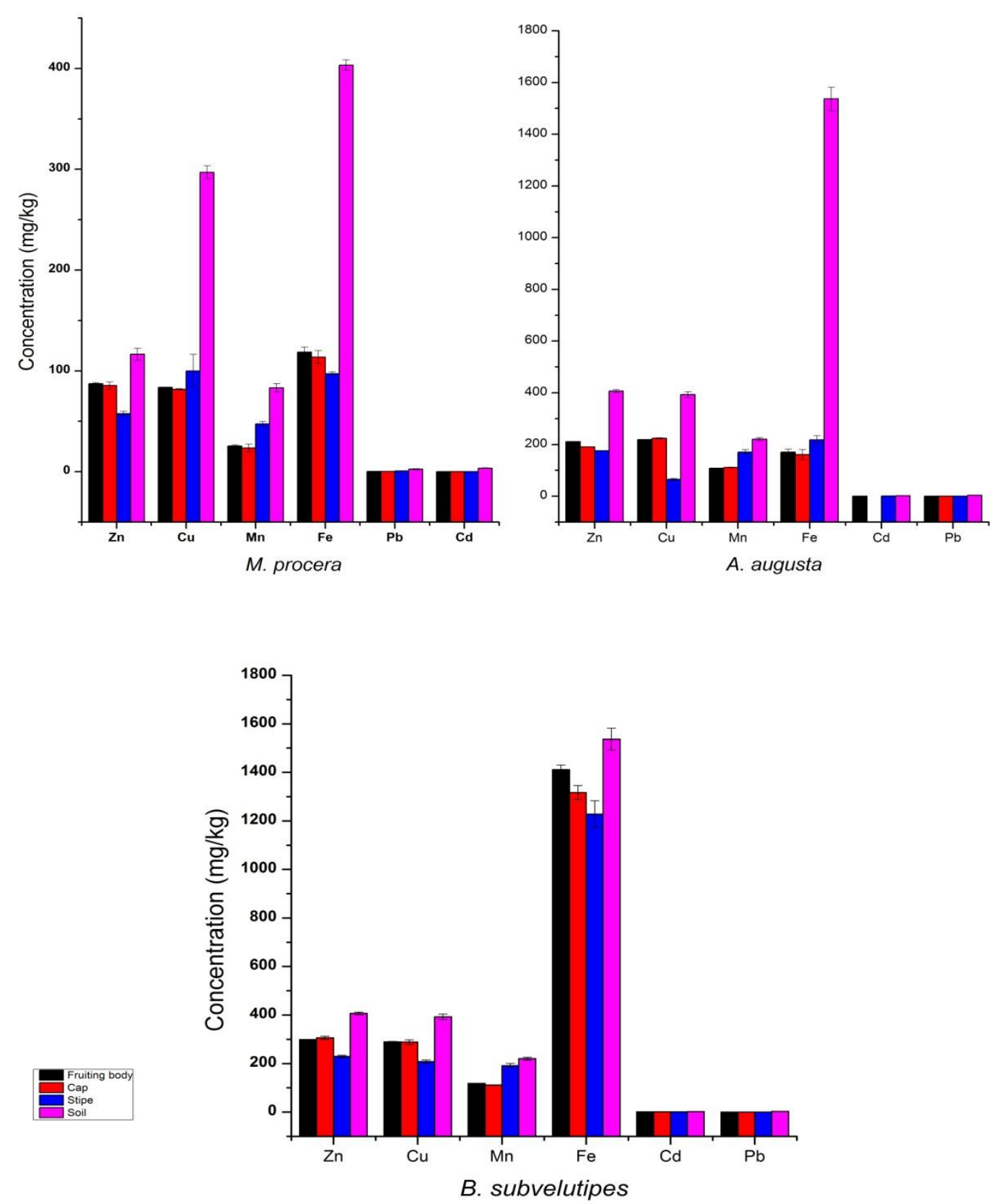

Fig. 1 - Graph showing concentration of minerals in three wild macrofungi $(\mathrm{Zn}, \mathrm{Cu}, \mathrm{Mn}, \mathrm{Fe}, \mathrm{Cd}, \mathrm{Pb})$

Similarly, the concentration of manganese ranged between $25.50 \pm 1.20 \mathrm{mg} / \mathrm{kg}$ in $M$. procera to $118.2 \pm 0.11 \mathrm{mg} / \mathrm{kg}$ in B. subvelutipes (Table 2 and Fig 1). Also, the level of this element was established to be assembling more in the stipe portion than pileus region depicting its lower range of translocation in the fruiting body of investigated mushrooms. Of the three studied macrofungi, $A$. augusta and B. subvelutipes showed higher bioaccumulation efficiency for this element from the soil. The reported manganese values in the literature for wild edible mushrooms are in the range of 5.54-135 $\mathrm{mg} / \mathrm{kg}$ (Genccelep et al. 2009). Manganese plays pivotal role in carbohydrate metabolism, calcium absorption and blood sugar regulation. As a component of the antioxidant enzyme such as superoxide dismutase (SOD), it helps fighting free radicals. However, higher Mn concentration may lead to various serious and ultimately disabling neurological effects in human (Mallikarjuna et al. 2013, Zahorcova et al. 2016). 
Table 2 The results of heavy metal analysis of three wild mushrooms collected from different forest areas in Jammu province.

\begin{tabular}{|c|c|c|c|c|c|c|c|}
\hline $\begin{array}{l}\text { Mushroom } \\
\text { species }\end{array}$ & $\begin{array}{l}\text { Sample/soil } \\
\text { analysed }\end{array}$ & $\mathbf{Z n}$ & $\mathbf{C u}$ & Mn & $\mathbf{F e}$ & $\mathbf{C d}$ & $\mathbf{P b}$ \\
\hline \multirow[b]{2}{*}{$\begin{array}{l}\text { Macrolepiota } \\
\text { procera }\end{array}$} & $\begin{array}{l}\text { Fruiting body } \\
\text { Cap }\end{array}$ & $\begin{array}{c}87.2 \pm 1.18 \\
85.5 \pm 3.59\end{array}$ & $\begin{array}{l}83.6 \pm 0.20 \\
81.7 \pm 0.60\end{array}$ & $\begin{array}{l}25.5 \pm 1.20 \\
23.6 \pm 3.80\end{array}$ & $\begin{array}{l}118.6 \pm 5.01 \\
113.7 \pm 6.40\end{array}$ & $\begin{array}{l}0.23 \pm 0.01 \\
0.24 \pm 0.03\end{array}$ & $\begin{array}{l}0.046 \pm 0.05 \\
0.097 \pm 0.00\end{array}$ \\
\hline & $\begin{array}{l}\text { Stipe } \\
\text { Soil * }\end{array}$ & $\begin{array}{l}57.6 \pm 2.30 \\
116.6 \pm 5.90\end{array}$ & $\begin{array}{l}100.0 \pm 16.40 \\
297.0 \pm 6.37\end{array}$ & $\begin{array}{l}47.4 \pm 2.55 \\
83.2 \pm 4.27\end{array}$ & $\begin{array}{l}97.2 \pm 1.92 \\
403.3 \pm 5.11\end{array}$ & $\begin{array}{l}0.65 \pm 0.29 \\
2.49 \pm 0.53\end{array}$ & $\begin{array}{l}0.043 \pm 0.01 \\
3.5 \pm 0.36\end{array}$ \\
\hline Amanita augusta & $\begin{array}{l}\text { Fruiting body } \\
\text { Cap } \\
\text { Stipe } \\
\text { Soil** }\end{array}$ & $\begin{array}{l}211.1 \pm 0.86 \\
190.8 \pm 0.91 \\
176.3 \pm 0.88 \\
406.6 \pm 5.77\end{array}$ & $\begin{array}{l}218.6 \pm 1.65 \\
223.9 \pm 2.55 \\
64.8 \pm 4.16 \\
393.0 \pm 11.26\end{array}$ & $\begin{array}{l}108 \pm 0.11 \\
111.2 \pm 1.16 \\
170.9 \pm 9.27 \\
220.6 \pm 6.11\end{array}$ & $\begin{array}{l}171.1 \pm 11.21 \\
160.9 \pm 19.28 \\
218.2 \pm 15.99 \\
1536.8 \pm 44.83\end{array}$ & $\begin{array}{l}0.61 \pm 0.11 \\
\mathrm{Nd} \\
0.75 \pm 0.17 \\
1.67 \pm 0.11\end{array}$ & $\begin{array}{l}0.41 \pm 0.03 \\
0.36 \pm 0.05 \\
0.47 \pm 0.05 \\
3.27 \pm 0.53\end{array}$ \\
\hline \multirow{3}{*}{$\begin{array}{l}\text { Boletus } \\
\text { subvelutipes }\end{array}$} & $\begin{array}{l}\text { Fruiting body } \\
\text { Cap }\end{array}$ & $\begin{array}{l}299 \pm 0.86 \\
306.5 \pm 6.53\end{array}$ & $\begin{array}{l}290 \pm 1.08 \\
288.8 \pm 9.23\end{array}$ & $\begin{array}{l}118.2 \pm 0.11 \\
111.2 \pm 1.16\end{array}$ & $\begin{array}{l}1411.1 \pm 18.6 \\
1316.6 \pm 28.86\end{array}$ & $\begin{array}{l}0.71 \pm 0.21 \\
0.76 \pm 0.02\end{array}$ & $\begin{array}{l}0.46 \pm 0.05 \\
0.36 \pm 0.05\end{array}$ \\
\hline & Stipe & $229.5 \pm 4.68$ & $207.7 \pm 6.72$ & $190.9 \pm 9.27$ & $1228.0 \pm 54.83$ & $0.98 \pm 0.02$ & $0.48 \pm 0.05$ \\
\hline & Soil** & $406.6 \pm 5.77$ & $393.0 \pm 11.26$ & $220.6 \pm 6.11$ & $1536.8 \pm 44.83$ & $1.67 \pm 0.11$ & $3.27 \pm 0.53$ \\
\hline
\end{tabular}

All the values are expressed as mean $\pm \mathrm{SE} ; *$ study area 1 (Udhampur); ** study area 2 (Patnitop).

The value of iron ranged $118.6 \pm 5.01 \mathrm{mg} / \mathrm{kg}$ in M. procera to $1411.6 \pm 18.60 \mathrm{mg} / \mathrm{kg}$ in $B$. subvelutipes respectively. Pileus of fruiting bodies of $M$. procera and $B$. subvelutipes possessed maximum level of Fe than stipe region. As evident from the Table 2 and Fig 1 , the poisonous species of $B$. subvelutipes showed highest bioaccumulation capacity for this element. Iron is vital for normal functioning of R.B.C's and oxygen transport. Also, adequate iron in a diet is very important in order to decrease the incidence of anaemia. On the contrary, the concentration of iron in the body should be tightly regulated as it can form free radical and may cause several neurodegenerative disorders (Nakalembe et al. 2015).

The concentration of cadmium in the investigated mushrooms ranged between $0.23 \pm 0.01 \mathrm{mg} / \mathrm{kg}$ to $0.71 \pm 0.21 \mathrm{mg} / \mathrm{kg}$ (Table 2 and Fig 1 ). Moreover, the cap portion of A. augusta showed no results for the presence of cadmium in the cap region. Higher concentration for this element was detected in the stipe portion than pileus region in all the three studied macrofungi. Of the three macrofungi studied, A. augusta and B. subvelutipes exhibited high accumulation rate for this metal. Cadmium is one of the heavy metals found in trace amount in the fruiting bodies of mushrooms and its higher amounts renders wild macrofungi unfit for human consumption as elevated levels of cadmium may pose a damage to immune system and lead to various psychological disorders (Soylak et al. 2005, Soylak \& Topalak, 2015, Zahorcova et al. 2016). 
Another toxic heavy metal namely lead showed maximum concentration in poisonous species of B. subvelutipes $(0.46 \pm 0.05 \mathrm{mg} / \mathrm{kg})$, while as minimum level was observed in the edible species of $M$. procera $(0.046 \pm 0.05 \mathrm{mg} / \mathrm{kg})$ (Table 2 and Fig 1). Comparatively, the stipe portion of $A$. augusta and $B$. subvelutipes showed higher efficiency for accumulation of this element than the cap region. Lead is a heavy metal that should be present in negligible amount in the cells as it interfers with a variety of body processes and is toxic to many tissues including the heart, bones, kidneys and reproductive systems (Das, 2005, Zahorcova et al. 2016).

Statistically the correlation between the metal content in soil and fruiting bodies of investigated mushroom species were estimated to be lower for $\mathrm{Pd}$ and were significant for $\mathrm{Cu}$ and $\mathrm{Fe}$ i.e. more than 1 , which means that these analysed mushrooms are accumulators and hyperaccumulators for these elements. The highest value of $\mathrm{Cu}$ and $\mathrm{Fe}$ were recorded in $B$. subvelupites.

The Pearson coefficient between metal content in soil and metal content in sample indicates that metal concentration is influenced by species, morphological part of the fruiting body and soil characteristics. The correlation has significance at level for $\mathrm{Zn}$ and $\mathrm{Mn}$ at $0.1 \%(\mathrm{p}<0.001)$ and $5 \%$ $(\mathrm{p}<0.005)$ for $\mathrm{Cu}, \mathrm{Cd}, \mathrm{Fe}, \mathrm{Pb}$.

\section{Conclusion}

Three wild mushrooms viz., Macrolepiota procera (edible species), Amanita augusta (nonedible species), Boletus subvelutipes (poisonous species) were investigated for the presence of six heavy metals $(\mathrm{Zn}, \mathrm{Cu}, \mathrm{Mn}, \mathrm{Fe}, \mathrm{Cd}, \mathrm{Pb})$ that revealed a significant variation in the capacity for the accumulation of these elements from the soil depending upon the type of mushroom and its part i.e stipe and pileus. The analysed metals were under permissible limit for $M$. procera, thus making it an easily accessible source of proteins and minerals for consumers. However, the other two analysed wild mushrooms (A. augusta and B. subvelutipes) reflected the presence of heavy metals in excess amounts than threshold concentration. This can be attributed to the fact that these two macrofungi undergo ectomycorrhizal association that in turn increase their efficiency to uptake metals from the soil (Krupa \& Kozdroj, 2004). Thus, further extensive assays on these two mushrooms are recommended to scrutinize their level of potent toxicity before dispensing them to pharmaceutical industry for incorporation into drugs and medicine. Our study comprises first report on the heavy metal estimation in these wild mushrooms and, therefore, this data can act as baseline for further research on heavy metal estimation in economically important wild growing mushrooms.

\section{Acknowledgements}

Thanks are due to the Head, Department of Botany, University of Jammu, Jammu and Kashmir, for providing laboratory facilities. The first author also gratefully acknowledges the financial support from DST (INSPIRE), New Delhi.

\section{References}

Das N 2005 - Heavy metals biosorption by mushrooms. Natural Product Radiance 4, 454-459.

Dulay RMR, Cabalar AC, De Roxas MJB, Concepcion JMP, Cruz NE, Esmeralda M, Jimenez N, Aguilar JC, De Guzman EJ, Santiago JQ, Samoy JR, Bustillos RG, Kalaw SP, Reyes RG 2015 Proximate composition and antioxidant activity of Panaeolus antillarium, a wild coprophilous mushroom. Current Research in Environmental and Applied Mycology 5(1), 52-59.

Elekes CC, Busuioc G, Ionita G 2010 -The bioaccumulation of some heavy metals in the fruiting body of wild growing mushrooms. Notulae Botanicae Horti Agrobotanici Cluj-Napoca 38, 147-151.

Frankowska A, Ziolkowska J, Bielawski L, Falandyz J 2010 - Profile and bioconcentration of minerals by King bolete (Boletus edulis) from the Plocka Dale in Poland. Food Additives and Contamination 3(1), 1-6.

Gadd GM 1993 - Interaction of fungi with toxic metal. New Phytologist 124, 25-60.

Genccelep H, Uzun Y, Tuncturk Y, Demirel K 2009 - Determination of mineral contents of wild grown edible mushrooms. Food Chemistry 113, 1033-1036. 
Gursoy N, Sarikurcku C, Cengiz M, Solak M 2009 - Antioxidant activities, metal contents, total phenolics and flavonoids of seven Morchella species. Food Chemistry and Toxicology 47 (9), 2381-2388.

Isildak O, Turkekul I, Elmastas M, Tuzen M 2004 - Analysis of heavy metals in some wild-grown edible mushrooms from the middle black sea region, Turkey. Food Chemistry 86, 547-552.

Kalac P, Svoboda L 2000 - A review of trace element concentrations in edible mushrooms. Food Chemistry 69, 273-281.

Keles A, Koca I, Gencelep H 2011 - Antioxidant properties of wild edible mushrooms. Journal of Food Processing and Technology 2, 2-6.

Krupa P, Kozdroj J 2004 - Accumulation of heavy metals by ectomycorrhizal fungi colonizing birch trees growing in an industrial desert soil. World Journal of Microbiology and Biotechnology 20, 427-430.

Magdziak Z, Mleczek M, Goliński P, Siwulski M, Szablewska KS 2013 - Concentration of minerals in selected edible mushroom species growing in Poland and their effect on human health. Acta Scientiarum Polonorum, Technologia Alimentaria 12(2), 203-214.

Mallikarjuna SE, Ranjini A, Haware JD, Vijayalakshmi MR, Shashirekha MN, Rajarathnam S 2013 Mineral composition of four edible mushrooms. Journal of Chemistry 2013, 1-5.

Manzi P, Aguzzi A, Pizzoferrato L 2001 - Nutritional value of mushrooms widely consumed in Italy. Food Chemistry 73, 321-325.

Mazurkiewicz N, Podlasinska J 2014 - Bioaccumulation of trace elements in wild-growing edible mushrooms from Lubuskie voivodeship, Poland. Chemistry and Ecology 30(2), 110-117.

Nakalembe I, Kabasa JD, Olila D 2015 - Comparative nutrient composition of selected wild edible mushrooms from two agro-ecological zones, Uganda. Springer Plus 4(1), 433.

Olumuyiwa SF, Oluwatoyin OA, Olanrewaja O, Steve RA 2007 - Chemical composition and toxic trace element composition of some Nigerian edible wild mushroom. International Journal of Food Science and Technology 43, 24-29.

Radulescu C, Stihi C, Busuioc G, Gheboianu AI, Popescu IV 2010 - Studies concerning heavy metals bioaccumulation of wild edible mushrooms from industrial area by using spectrometric techniques. Bulletin of Environmental Contamination and Toxicology 84, 641-646.

Soylak M, Saracodlu S, Tuzen M, Mendil D 2005 - Determination of trace metals in mushroom samples from Kayseri, Turkey. Food Chemistry 92, 649-652.

Soylak M, Topalak Z 2015 - Enrichment-separation and determinations of cadmium (II) and lead (II)1-phenyl-1H-tetrazole-5-thiol chelates on Diaion SP-207 by solid phase extraction-flame atomic absorption spectrometry. Arabian Journal of Chemistry 8(5), 720-725.

Tuzen M, Turkekul I, Hasdemir E, Mendil D, Sari H 2003 - Atomic absorption spectrometric determination of trace metal contents of mushroom samples from Tokat, Turkey. Analytical Letters 36, 1401-1410.

Yildiz O, Can Z, Laghari AQ, Sahin H, Malkoe M 2015 - Wild edible mushrooms as a natural source of phenolics and antioxidants. Journal of Food Biochemistry 39, 148-154.

Zahorcova Z, Arvay J, Hauptvogl M, Tomas J, Harangozo L 2016 - Heavy metals determination in edible wild mushrooms growing in former mining area Slovakia: Health risk assessment. Potravinarstvo Scientific Journal for Food Industry 10, 37-46.

Zhu F, Qu L, Fan W, Qiao M, Hao H, Wang X 2011 - Assessment of heavy metals in some wild edible mushrooms collected from Yunnan Province, China. Environmental Monitoring and Assessment 179, 191-199. 